\title{
Metal nanoparticles as an electromagnetic microwave heat-cure agent for polydimethylsiloxane elastomers
}

\author{
E. V. Antonov ${ }^{1}$, I. M. Sosnin ${ }^{1,2}$, A. Tiwari ${ }^{3}$, N. D. Prasolov ${ }^{1,4}$, L. M. Dorogin ${ }^{\dagger, 1}$ \\ †leonid.dorogin@majorrevision.com
}

${ }^{1}$ Saint Petersburg National Research University of Information Technologies, Mechanics and Optics (ITMO University),

St. Petersburg, 197101, Russia

${ }^{2}$ Togliatti State University, Togliatti, 445020, Russia

${ }^{3}$ PGI-1, Forschungszentrum Juelich, Jülich, 52425, Germany

${ }^{4}$ Ioffe Institute, St. Petersburg, 194021, Russia

\begin{abstract}
Most commonly polydimethylsiloxane (PDMS) elastomer (silicone) is obtained from prepolymer liquid by cross-linking reaction (curing) at room temperature or assisted by external heating. However, in special cases, such as medical applications, it could be useful to cure the elastomeric material selectively and/or without external heat. An ability for customized curing can be controlled by selection of special type of fillers, such as metal particles or carbon nanotubes for curing routed via Joule heat, magnetic induction or electromagnetic microwave radiation. There are number of reasons for microwave curing to be preferred: microwave curing does not require heat conductivity of the surrounding medium, microwave energy can be directly delivered to select part of the material, this also allows for energy saving. Dielectric (internal) heating by microwave radiation is not efficient for pristine PDMS due to non-polar nature of this substance. Higher chemical polarity additives to PDMS could facilitate internal heating. We test silver nanoparticles (Ag NPs) for using as internal heating agent for PDMS elastomer kit (Sylgard 184). A set of general properties of the resultant PDMS/AgNPs composite material, including dynamic mechanical analysis (DMA), water wetting contact angle, adhesion to glass and optical spectroscopy of the filled PDMS are evaluated herein. The obtained composite materials exhibit a significantly higher work of adhesion, a lower viscoelastic modulus and slightly higher wettability. With time of microwave treatment and consequently cross-linking of the material those parameters head towards or approach those of the stock PDMS material.
\end{abstract}

Keywords: polydimethylsiloxane, cross-linking, curing, silver, nanoparticles, microwave, radiation.

\section{Металлические наночастицы как отвердительная добавка при электромагнитной микроволновой обработке полидиметилсилоксановых эластомеров}

\author{
Антонов Е. В. ${ }^{1}$, Соснин И. М. ${ }^{1,2}$, Тивари А. ${ }^{3}$, Прасолов Н. Д. ${ }^{1,4}$, Дорогин Л. М., \\ ${ }^{1}$ Санкт-Петербургский национальный исследовательский университет информационных технологий, механики \\ и оптики (ИТМО), Санкт-Петербург, 197101, Россия \\ ${ }^{2}$ Тольяттинский государственный университет, Тольятти, 445020 , Россия \\ ${ }^{3}$ Юлихский исследовательский центр, Юлих, 52425, Германия \\ ${ }^{4}$ Физико-технический институт им. А.Ф. Иоффе РАН, Санкт-Петербург, 194021, Россия
}

Полидиметилсилоксановый (ПДМС) эластомер (силикон) обычно получают из жидкого преполимера путем реакции сшивания (отверждения) при комнатной температуре или с помощью внешнего нагрева. Однако в особых случаях, таких как медицинские применения, может быть полезно отверждение эластомерного материала выборочно и/или без внешнего нагрева. Возможность такого адресного отверждения можно контролировать путем выбора специального типа наполнителей, таких как частицы металла или углеродные нанотрубки, для отверждения, направляемого посредством джоулева тепла, магнитной индукции или электромагнитного микроволнового излучения. Существует ряд причин, по которым микроволновое отверждение может быть предпочтительным: для микроволнового отверждения не требуется теплопроводность окружающей среды, микроволновая энергия может подаваться непосредственно на выбранную часть материала, кроме того, это позволяет экономить энергию. Диэлектрический (внутренний) нагрев микроволновым излучением неэффективен для стандартных ПДМС 
компаундов из-за неполярной природы этого вещества. Добавки с более высокой химической полярностью к ПДМС могут способствовать более эффективному внутреннему нагреву. Мы испытали наночастицы серебра (Ag NPs) для использования в качестве внутреннего нагревателя для эластомерного набора ПДМС Sylgard 184 . B статье оценивается набор общих свойств полученного композитного материала PDMS/AgNPs, включая динамический механический анализ (DMA), краевой угол смачивания водой, адгезию к стеклу и оптическую спектроскопию наполненного ПДМС. Полученные композитные материалы демонстрируют значительно более высокую работу адгезии, более низкий модуль вязкоупругости и немного более высокую смачиваемость. Со временем обработки микроволнами и, как следствие, сшивки материала, эти параметры приближаются к параметрам материала ПДМС стандартной композиции.

Ключевые слова: полидиметилсилоксан, сшивание, отверждение, серебро, наночастицы, микроволновый, излучение.

\section{Introduction}

Design of flexible electronics devices requires a very rigorous selection of materials. The basic factors used for evaluating materials for flexible electronics include mechanical (flexibility, adhesion, stretchability), and electrical (conductivity) properties. In addition to the named basic factors, more properties are often required, such as: chemical (stability, chemical activity), biocompatibility, thermal (stability, conductivity), optical (transparency). Polydimethylsiloxane (PDMS) appears to be one of the most common choices as a base polymer for flexible electronics, in particular due the ease of production and bio-compatibility. Silver nanoparticles (Ag NPs) and nanowires (Ag NWs) are often combined with PDMS [1] as a filler for wearable [2 -4], sensorics [5,6], biological [7] and medical [8] applications. It is generally known that PDMS-based materials offer high flexibility and stretchability, and their surface is expected to be hydrophobic, but the exact functional properties can strongly depend on the material content and processing.

Adhesion and wetting phenomena play a crucial role in manufacturing and exploitation of the flexible PDMS/AgNP based devices. Multilayer flexible devices must be designed with adhesion in mind to withstand large deformation without delamination. Wearable devices need to be washable, whether it is smart clothes, or skin-attached sensors for medical applications.

PDMS-based materials are produced from liquid prepolymer by cross-linking, also called "curing". Curing of PDMS-based materials can be realized at room temperature or assisted by external heat. Several alternative technologies had been already proposed for curing of PDMS-based materials that might be useful in special environments like biological tissues or vacuum. An ability for custom curing is controlled by the special type of fillers, such as iron particles for magnetic induction curing [9], carbon nanotubes for Joule heat curing [10] and for electromagnetic microwave radiation curing [11]. There are several reasons that make the microwave curing the most preferred one. First, it does not require heat conductivity of the surrounding medium, thus can be used in vacuum. Second, microwave energy can be directly delivered to a selected part of the cured material. Finally, microwave curing allows to save energy.

In spite of the high interest to Ag NPs as a filler for PDMS from the scientific community, the possibility for microwave curing of PDMS/AgNP has been unexplored so far. In this paper, we will evaluate a set of basic properties of electromagnetic microwave cured PDMS/AgNP compound.
This work contains the first experimental data on the electromagnetic microwave radiation treated PDMS/AgNP, including its viscoelastic moduli, surface (contact) properties and optical spectroscopy.

\section{Fabrication of silicone compounds}

A set of silicone elastomer samples were produced for this study according to Table 1. All samples were prepared using Sylgard 184 (Dow Corning, USA) elastomer kit in a base/crosslinker mass ratio of $10: 1$. This stock compound cures in 48 hours at room temperature; at the same time, this process can be accelerated by heat treatment at $100-150^{\circ} \mathrm{C}$ for up to 35-10 minutes according to the manufacturer's documentation. The Ag NPs used in the present study were synthesized using a modified method of reducing the metal ions to their atomic state followed by crystallization and had a diameter of 35-120 nm [12]. To make easy a uniform distribution of Ag NPs in the PDMS precursor, the nanoparticles were prepared in the form of an ethanol suspension. The total mass of each silicone prepolymer liquid was $5 \mathrm{~g}$. In all samples the amount of ethanol was $1.577 \mathrm{~g}$. The content of silver in the PDMS/AgNP liquid prepolymer was $0.01 \%$ by mass of the final compound.

Mixing was carried out using a SpeedMixer (TM) DAC 150.1 FVZ (Hauschild Eng., Germany) at $3500 \mathrm{rpm}$ for $40 \mathrm{~s}$. The samples were exposed to microwave irradiation at a power of $700 \mathrm{~V}$ and a frequency of $2450 \mathrm{MHz}$ for 0 to 4 hours (Fig. 1).

\section{Properties of the silicone compounds and discussion}

\subsection{DMA measurements of viscoelasitc properties}

To understand how the microwave cured PDMS/AgNP materials compare with the stock PDMS material in terms of viscoelastic properties, dynamic mechanical analysis (DMA) was performed on the solidified materials containing silver nanoparticles and/or irradiated with microwave radiation (Fig. 2a). A Q800 dynamic mechanical analysis (DMA) instrument (TA Instruments, USA) was used for the measurements operated in tension mode by an applied sinusoidal stress in high-strain and low-strain conditions.

Strain sweep experiments were performed using dynamic mechanical analysis (DMA) with strain amplitudes up to $50 \%$ at constant temperature $\left(20^{\circ} \mathrm{C}\right)$ and constant low frequency $(1 \mathrm{~Hz})$ for all samples listed in the Table 1. 


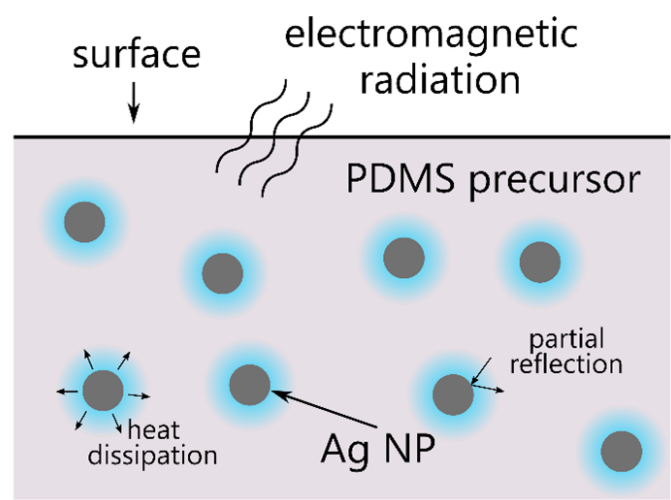

Fig. 1. (Color online) Schematics of the physical principles underlying electromagnetic microwave radiation assisted curing of silver nanoparticle (Ag NP) filled polydimethylsiloxane (PDMS) prepolymer liquid. Ag NPs act as antennas by absorbing electromagnetic energy and releasing a part of this energy as heat.

The complex viscoelastic modulus was also obtained for PDMS/AgNP@4hMW. It is measured in constant-amplitude low-strain deformation mode with a deformation amplitude of $0.04 \%$ and at different frequencies ("frequency sweep"), starting from $28 \mathrm{~Hz}$, and changes stepwise until reaching $0.25 \mathrm{~Hz}$ (10 frequency points: 28.0, 25.0, 14.0, 7.9, 4.4, 2.5, 1.4, $0.79,0.44$ and $0.25 \mathrm{~Hz}$ ) [14]. The experiment began with rapid cooling of the sample to $-140^{\circ} \mathrm{C}$, then measuring viscoelastic modulus at a given temperature on all frequency listed above, and later the temperature was gradually increased by $5^{\circ} \mathrm{C}$ in a loop. The procedure was repeated until $120^{\circ} \mathrm{C}$ was reached, so viscoelastic module $\operatorname{Re}(E)$ from temperature were obtained.

To obtain the function of the real part of the viscoelasticity modulus $\operatorname{Re}(E)$ of the angular frequency $\omega$, the frequencytemperature shift method based on the time-temperature superposition (TTS) principle was used, which is described in details in [15]. As a result, the experimental data were converted into a dependence of viscoelasticity on wide range of frequencies (Fig. 2 b). It is worth noting the dashed line in the plot, which arises from the hysteresis of DMA response of the material in variable temperature conditions, and could be attributed to crystallization in the material [13].
DMA literature data on Sylgard 184 PDMS elastomer material 1:10, 1:20, 1:30 without fillers are known from the article [13]. In general, the viscoelasticity master-curve and the strain sweep curves of fabricated material has a typical shape for PDMS elastomer materials.

Based on the analysis of all DMA results (see Table 1), the following conclusions can be drawn:

1. Materials with Ag NPs without microwave treatment (PDMS/AgNP@0hMW) are the softest materials in the set (Table 1). PDMS/AgNP@0hMW has a 19.2\% lower elastic modulus (low-strain) compared to the stock PDMS material;

2. Microwave irradiation tends to increase the elastic modulus of the composite elastomers, both for stock PDMS material (9.5\% increase in 4 hours) and for PDMS/AgNP composite material (19.7\% increase in 4 hours).

3. Viscoelastic properties of composite material microwave-treated for 4 hours (PDMS/AgNP@4hMW) approach to the stock PDMS material - the difference is $2.3 \%$ for low-strain elastic modulus.

\subsection{Adhesion properties and contact angle}

\subsubsection{Adhesion to glass}

We have studied adhesive interaction between glass and the fabricated elastomers in custom-made Johnson-KendallRoberts (JKR) inspired adhesion testing setup described in details in Ref. $[13,14]$. In each contact cycle, the loading force is about $0.1 \mathrm{~N}$, and the vertical speed $4.68 \cdot 10^{-5} \mathrm{~m} / \mathrm{s}$. During retraction the interaction between the glass ball and the PDMS sample is fully broken. Work of adhesion was found using the JKR model [16] and presented in Table 1. Based on Table 1, the following general conclusions can be drawn:

1. With the addition of silver NPs without microwave treatment, the work of adhesion is increased (approximately 4 times compared to the stock PDMS).

2. After microwave treatment of the material with silver NPs filler, the work of adhesion is decreased (1.86 times for PDMS/AgNP@4hMW compared to PDMS/AgNP).

3. In composites containing silver nanoparticles under microwave treatment, the work of adhesion decreases more

Table 1. Table of fabricated elastomer materials and the main measured properties. The sample label is encoded with the base material, the additional component (if any, via/), as well as curing conditions.

\begin{tabular}{|c|c|c|c|c|}
\hline Sample label & $\begin{array}{c}\text { Relative weight of silver } \\
\text { nanoparticles, } \%\end{array}$ & $\begin{array}{c}\text { Curing conditions (room } \\
\text { temperature - RT) }\end{array}$ & $\begin{array}{c}\text { Work of adhesion* } \\
\mathrm{J} / \mathrm{m}^{2}\end{array}$ & $\begin{array}{c}\text { Storage modulus } \\
\text { (low-strain), MPa }\end{array}$ \\
\hline PDMS (stock) & 0 & Only RT & 0.44 & 1.68 \\
\hline PDMS@1hMW & 0 & Microwave treated 60 min & 0.41 & 1.73 \\
\hline PDMS@2hMW & 0 & Microwave treated 120 min & 0.35 & 1.84 \\
\hline PDMS@3hMW & 0 & Microwave treated 180 min & 0.34 & 1.69 \\
\hline PDMS@4hMW & 0 & Microwave treated 240 min & 0.28 & 1.84 \\
\hline PDMS/AgNP@0hMW & 0.01 & Only RT & 1.72 & 1.37 \\
\hline PDMS/AgNP@1hMW & 0.01 & Microwave treated 60 min & $>1.39^{* *}$ & 1.61 \\
\hline PDMS/AgNP@2hMW & 0.01 & Microwave treated 120 min & 0.88 & 1.52 \\
\hline PDMS/AgNP@3hMW & 0.01 & Microwave treated 180 min & 0.8 & 1.47 \\
\hline PDMS/AgNP@4hMW & 0.01 & Microwave treated 240 min & 0.91 & 1.64 \\
\hline
\end{tabular}

${ }^{\star}$ Relative statistical error of the adhesion measurements from more than 10 repeated contacts is within $10 \%$.

${ }^{*}$ Lower boundary indicated due to the adhesion of the sample being too strong for the used experimental conditions. 


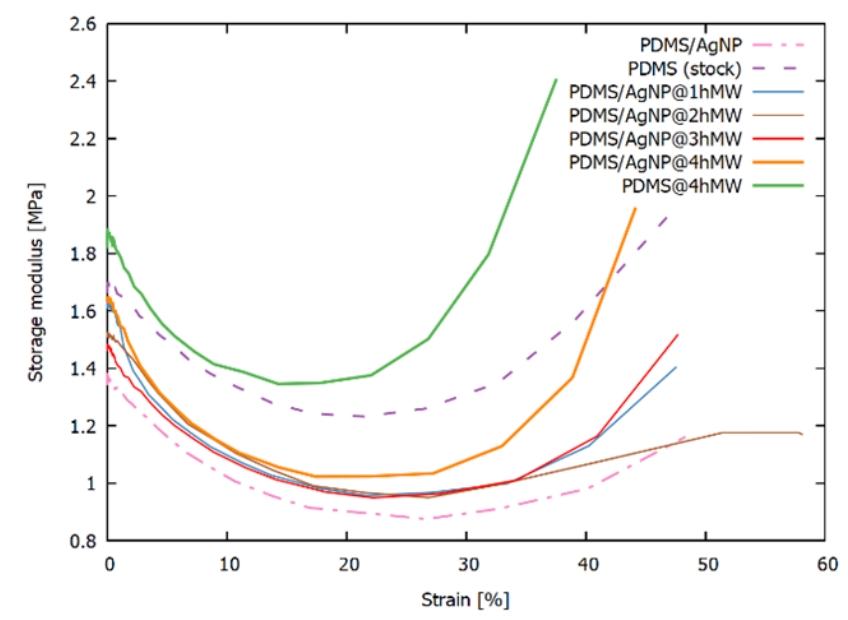

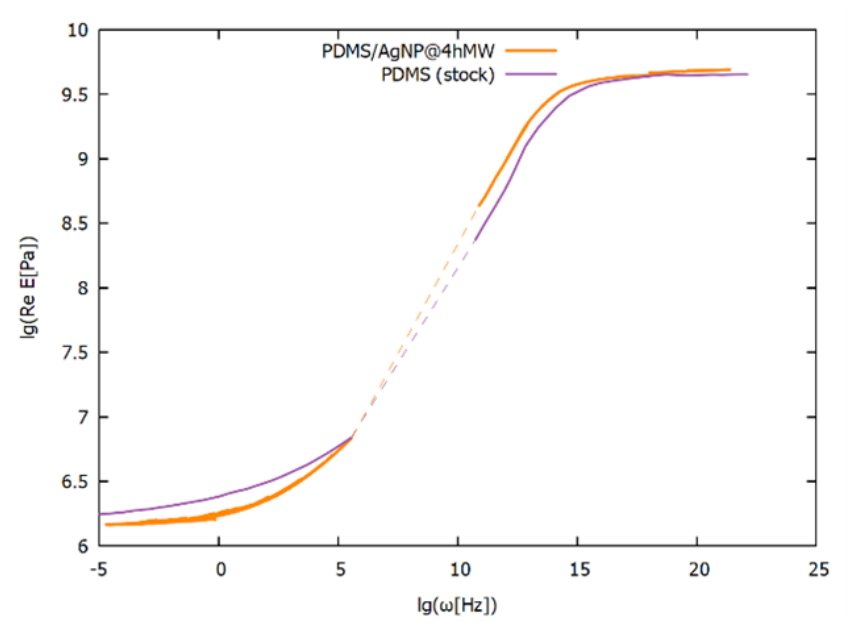

$\mathrm{b}$

Fig. 2. (Color online) Strain sweep via dynamic mechanical analysis (DMA) of standard and PDMS/AgNPs compounds. Results of measurement of storage modulus (Re $E$ ) as a function of strain at constant ambient temperature $\left(20^{\circ} \mathrm{C}\right)(\mathrm{a})$. Master curve via Dynamic Mechanical Analysis (DMA) of standard and PDMS/AgNP compound (b). Results of measurements of the viscoelastic modulus (Re E) as a function of the excitation frequency $\omega$ at small deformations using DMA with temperature variation and subsequent reconstruction of the data for one reference temperature $\left(20^{\circ} \mathrm{C}\right)$ using time-tempereature superposition (TTS). The dash line shows the linearly interpolated behavior of Re $E$ in the interval where the DMA measurement did not reveal unambiguous data for applying TTS (see the discussion on the phase transition in PDMS [13]).

strongly than for the silver-free compounds (1.89 times versus 1.57 times).

4. The work of adhesion of the sample with silver nanoparticles after 4 hours of microwave treatment (PDMS/AgNP@4hMW) is still about twice higher than that of the stock PDMS material.

\subsubsection{Water contact angle}

We have also measured the adhesion (wetting) of elastomer surface to water as one of the indicators of the polarity of the surface. In a series of experiments advancing $\theta_{\mathrm{A}}$ and receding $\theta_{\mathrm{R}}$ contact angles for water on the elastomer surface were measured. The measurements were performed by depositing a small water droplet (4-6 mm diameter) on the elastomer surface. The advancing contact angle was determined after waiting approximately $1 \mathrm{~min}$ at which point no movement of the contact line could be detected. The receding contact angle was determined by studying the water droplet during evaporation of the water. When enough water had evaporated the contact line started to move inwards and at this point we measured the receding contact angle (see also for details on the method [14]). After that, according to Ref. [14], the equilibrium $\theta_{C}$ contact angle was found for the stock PDMS, PDMS@4hMW, PDMS/AgNP@0hMW and PDMS/AgNP@4hMW, and were equal to $74.41^{\circ} ; 117.77^{\circ} ; 82.38^{\circ}$ and $56.76^{\circ}$, respectively, with statistical error estimation of $10^{\circ}$. It should be noted that the difference between advancing and receding angles was less than $18^{\circ}$, a low figure which could indicate a smooth and homogeneous surface. However, it is worth noting that the sample containing no silver nanoparticles and treated for 4 hours (PDMS@4hMW) had significantly reduced wettability, while the material containing nanoparticles of silver and treated for 4 hours (PDMS/AgNP@4hMW) significantly increased wettability compared to the stock PDMS. The reason behind the first observation is not exactly clear and might lay in the rearrangement or evaporation of the minor chemical components on the surface. The second observation, increased wettability could be explained by migration of microwave radiation heated silver clusters resulting in the increased polarity of the surface.

\section{Optical spectroscopy}

We also obtained optical spectra of the stock PDMS materials, silver-containing PDMS material and silver-free PDMS material treated with microwave radiation. A UV/VIS absorption spectrometer instrument Ava-Absorbance (Avantes, Netherlands) was used for measuring the UV/VIS (200-1100 nm) absorption spectra of the PDMS-based materials as depicted in Fig. $3 \mathrm{~b}$. The spectrum of samples containing silver did not change noticeably with microwave treatment, and the respective data were not plotted. It can also be seen from the figure that microwave treatment had no pronounced effect on the silver-free PDMS materials.

The addition of silver nanoparticles to PDMS, firstly, reduced the overall transparency of the composite material, and, secondly, added an absorption peak at $415 \mathrm{~nm}$, which corresponds to the absorption peak of silver [12]. Nevertheless, the low silver content made it possible to retain the most of optical transparency of the PDMS/AgNP composite material.

\section{Conclusions}

We tested silver nanoparticles (Ag NPs) for using as internal heating agent for PDMS elastomers cured by microwave radiation. General properties of the silver-filled composite PDMS materials, including dynamic mechanical 


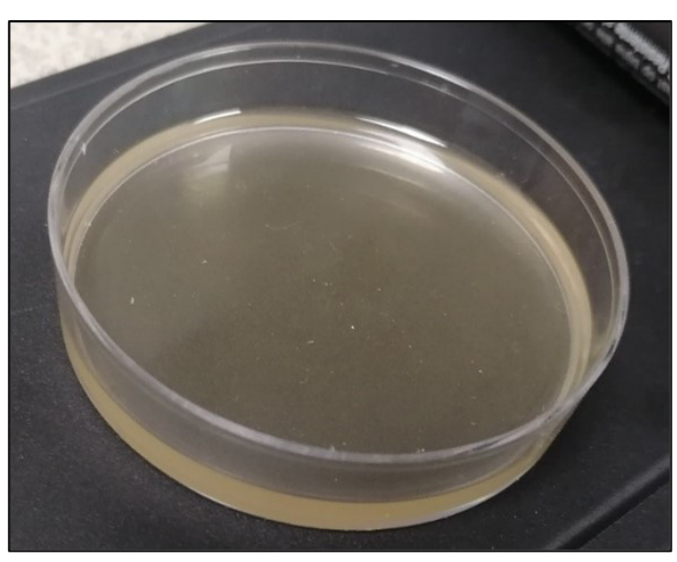

a

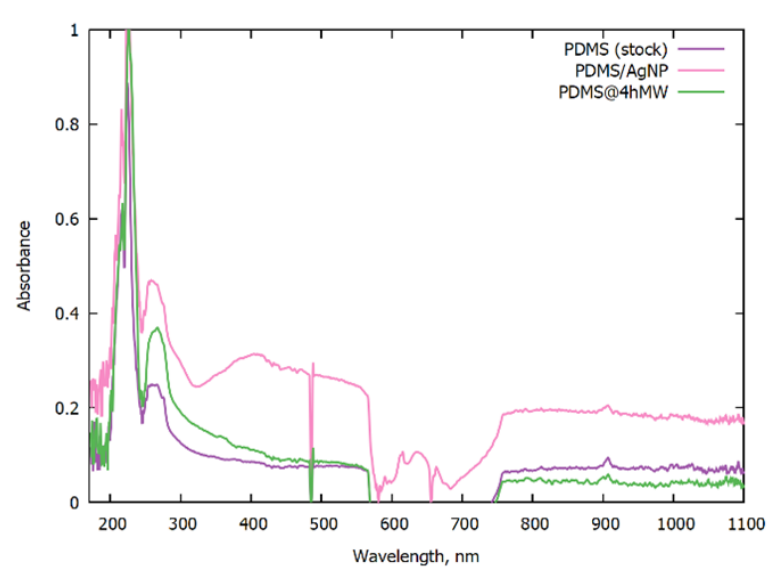

b

Fig. 3. (Color online) Silver nanoparticles (Ag NPs) filled polydimethylsiloxane (PDMS): photograph of the cured material with AgNP (a); transmittance (absorption) optical spectra of the stock PDMS material, the sample with 4-hours treatment and PDMS material with $\operatorname{AgNP}(\mathrm{b})$.

analysis, water wetting contact angle, adhesion to glass and optical transmission of the filled PDMS were evaluated in comparison with the silver-free stock PDMS material under room-temperature and microwave curing conditions.

The silver-filled materials (PDMS/AgNP) appeared to be generally softer (lower elastic modulus) and stronger adhesion to glass compared to the silver-free PDMS materials. The specimens containing silver and exposed to microwave irradiation for 4 hours (PDMS/AgNP@4hMW) in terms of their elastic properties approached the stock PDMS material cured at room temperature. However, adding silver NPs significantly altered surface properties of the elastomers as observed before and after microwave treatment as well.

Thus, one can conclude, that silver NPs can serve as a heatcure agent in PDMS-based elastomers for electromagnetic microwave curing conditions with the silver presence having little effect on its viscoelastic properties and introducing large change in surface properties, compared with the stock PDMS material.

Acknowledgements. This work was supported by the Ministry of Science and Higher Education of the Russian Federation (agreement nr. 075-15-2021-1349).

\section{References}

1. F. Xu, Y.Zhu. Adv. Mater. 24, 5117 (2012). Crossref

2. M. Amjadi, A. Pichitpajongkit, S. Lee, S. Ryu, I. Park. ACS Nano. 8, 5154 (2014). Crossref

3. G.-W. Huang, H.-M. Xiao, S.-Y.Fu. Sci. Rep. 5, 13971 (2015). Crossref

4. S. Shengbo, L. Lihua, J. Aoqun, D. Qianqian, J. Jianlong,
Z. Qiang, Z. Wendong. Nanotechnology. 29, 255202 (2018). Crossref

5. Y. Joo, J. Byun, N. Seong, J. Ha, H. Kim, S. Kim, T. Kim, H. Im, D. Kim, Y. Hong. Nanoscale. 7, 6208 (2015). Crossref

6. C.-J. Lee, K. H. Park, C. J. Han, M. S. Oh, B. You, Y.-S. Kim, J.-W. Kim. Sci. Rep. 7, 7959 (2017). Crossref

7. S. Jiang, C. P. Teng. Mater. Sci. Eng. C. 70, 1011 (2017). Crossref

8. R. Helgason, A. Banavali, Y.Lai. Med. DEVICES Sens. 2, e10025 (2019). Crossref

9. L. Al-Harbi, M. Darwish, M. Khowdiary, I. Stibor. Polymers. 10, 507 (2018). Crossref

10. S.-H. Jang, D. Kim, Y.-L. Park. Materials. 11, 1775 (2018). Crossref

11. B. Herren, P. Larson, M. Saha, Y. Liu. Polymers. 11, 1212 (2019). Crossref

12. I. A. Orlov, T.P. Sankova, P.S. Babich, I.M. Sosnin, E. Y. Ilyechova, D. A. Kirilenko, P. N. Brunkov, G. L. Ataev, A.E. Romanov, L. V. Puchkova. Int. J. Nanomedicine. 11, 6561 (2016). Crossref

13. A. Tiwari, L. Dorogin, A.I. Bennett, K.D. Schulze, W. G. Sawyer, M. Tahir, G. Heinrich, B. N. J. Persson. Soft Matter. 13, 3602 (2017). Crossref

14. L. Dorogin, A. Tiwari, C. Rotella, P. Mangiagalli, B.N. J. Persson. J. Chem. Phys. 148, 234702 (2018). Crossref

15. B. Lorenz, W. Pyckhout-Hintzen, B.N. J. Persson. Polymer. 55, 565 (2014). $\underline{\text { Crossref }}$

16. K. L. Johnson, K. Kendall, A.D. Roberts, D. Tabor. Proc. R. Soc. Lond. Math. Phys. Sci. 324, 301 (1971). $\underline{\text { Crossref }}$ 